\title{
Experimental Study of the Slit Spacing and Bed Height on the Thermal Performance of Slit-Glazed Solar Air Heater
}

\author{
Seyyed Mahdi Taheri Mousavi and Fuat Egelioglu \\ Mechanical Engineering Department, Eastern Mediterranean University, Famagusta, Northern Cyprus, Mersin 10, Turkey \\ Correspondence should be addressed to Seyyed Mahdi Taheri Mousavi; smahditaherim@gmail.com
}

Received 22 March 2017; Revised 15 June 2017; Accepted 20 June 2017; Published 30 July 2017

Academic Editor: Santolo Meo

Copyright (C) 2017 Seyyed Mahdi Taheri Mousavi and Fuat Egelioglu. This is an open access article distributed under the Creative Commons Attribution License, which permits unrestricted use, distribution, and reproduction in any medium, provided the original work is properly cited.

\begin{abstract}
The thermal performances of three slit-glazed solar air heaters (SGSAHs) were investigated experimentally. Three SGSAHs with different bed heights $(7 \mathrm{~cm}, 5 \mathrm{~cm}$, and $3 \mathrm{~cm})$ were fabricated with multiple glass panes used for glazing. The length, width, and thickness of each pane were $154 \mathrm{~cm}, 6 \mathrm{~cm}$, and $0.4 \mathrm{~cm}$, respectively. Ambient air was continuously withdrawn through the gaps between the glass panes by fans. The experiments were conducted for four different gap distances between the glass panes $(0.5 \mathrm{~mm}, 1 \mathrm{~mm}, 2 \mathrm{~mm}$, and $3 \mathrm{~mm})$ and the air mass flow rate was varied between $0.014 \mathrm{~kg} / \mathrm{s}$ and $0.057 \mathrm{~kg} / \mathrm{s}$. The effects of air mass flux on the outlet temperature and thermal efficiency were studied. For the SGSAH with bed height of $7 \mathrm{~cm}$ and glass pane gap distance of $0.5 \mathrm{~mm}$, the highest efficiency was obtained as $82 \%$ at a mass flow rate of $0.057 \mathrm{~kg} / \mathrm{s}$ and the air temperature difference between the inlet and the outlet $(\Delta T)$ was maximum $\left(27^{\circ} \mathrm{C}\right)$ when the mass flow rate was least. The results demonstrate that for lower mass flow rates and larger gaps, the performance of SGSAH with a bed height of $3 \mathrm{~cm}$ was better compared to that of others. However, for higher mass flow rates, the SGSAH with $7 \mathrm{~cm}$ bed height performed better.
\end{abstract}

\section{Introduction}

Solar air heater (SAH) is a device which utilizes solar energy to heat air. For instance, they are used in space heating and drying crops in agriculture and in the industries. The collectors of SAHs can be divided into two main categories as unglazed transpired collector (UTC) and glazed untranspired collector (GUC). A conventional SAH is a GUC which has low thermal efficiency owing to high thermal losses from glazing along with low heat transfer coefficient between air and the absorber plate. Several studies have been undertaken in order to improve thermal efficiencies of SAHs where the main aim is to increase the convective heat transfer between the absorber plates and the working fluid while trying to minimize heat loss from the collectors. In order to decrease the heat loss from glazing, several studies have been performed with double glazing and different air mass flow rates.

The results of experimental and numerical investigations show that heat transfer enhancement is achieved by employing baffled double-pass procedures with external recycling and fins attached on both sides of the absorber plate [1]. The thermal efficiency of a double-pass GUC with fins packed with wire mesh, instead of an absorber plate, is found to be higher than the single pass by $7-19.4 \%$ [2]. The results of a double-pass GUC, designed and constructed by Wazed et al. [3], with forced and natural air flows demonstrate that the maximum temperature rise for forced circulation is $12.25^{\circ} \mathrm{C}$ and $8.5^{\circ} \mathrm{C}$ for natural circulation. The effects of different glazing materials (double glass, single glass, and polymethyl methacrylate) on the performance of a collector were investigated experimentally by Das and Chakraverty [4], who indicated that the outlet air temperature for a double-glass collector is $1^{\circ} \mathrm{C}$ and $2^{\circ} \mathrm{C}$ higher, respectively, for single-pass and polymethyl methacrylate-glazed collectors. The thermal efficiencies of collectors with double-glass, single-pass, and polymethyl methacrylate glazing are $46 \%$, $42 \%$, and $36.5 \%$, respectively. Further, it was noted, after observing over a period of three months, that the solar transmittance of polymethyl methacrylate decreases. The experimental results of El-sebaii et al. [5] indicated that using 


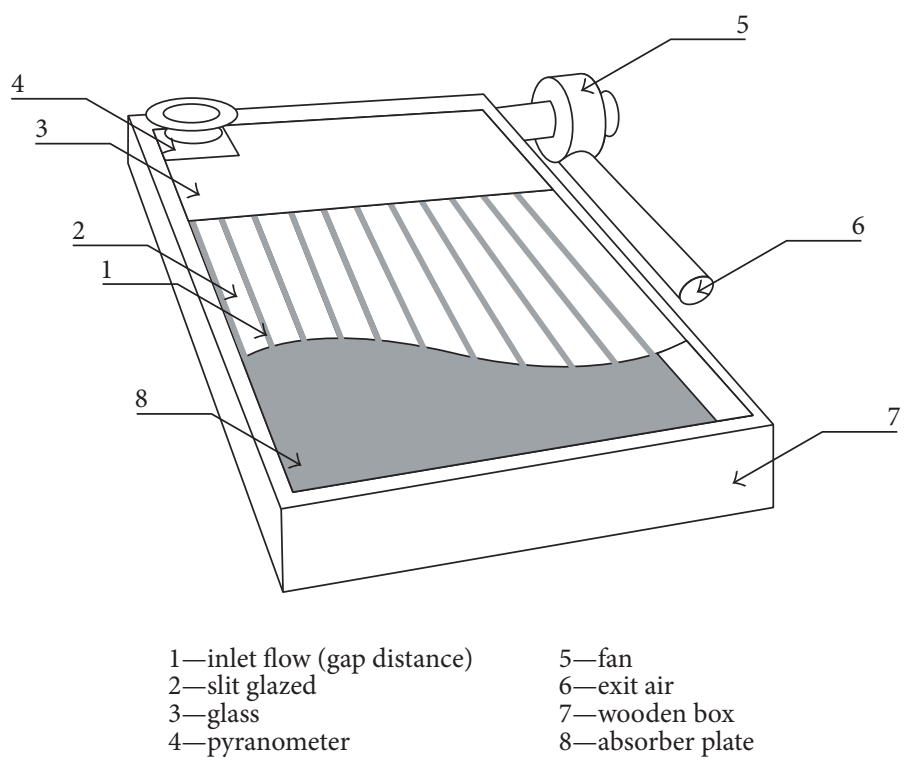

FIGURE 1: Schematic view of the slit-glazed collector system.

finned plate improves the thermal efficiency of double-pass v-corrugated plate GUC by $9.3-11.9 \%$ compared to the double-pass finned plate GUC.

In order to improve the heat transfer, roughness inducing wires and wavy passage were tried in various studies [6-8]. Different fin types, such as offset strip fins $[9,10]$ and continuous fins [11, 12], have been studied extensively. It was observed that introducing obstacles in the air stream increases the absorber plate surface area [13]. Fins are employed in the SAH to extend the surface area of the absorber [14]. The results of attaching pin fins to the absorber plate of SAH indicate that the efficiency improves by $48 \%$ compared to SAH without fins [15]. Deo et al. [16] studied the performance of a SAH with multigap $\mathrm{V}$-down rib combined with staggered ribs. Hans et al. [17] used multiple V-rib roughnesses in their design. Some researchers have investigated the effect of using porous materials in the collector which shows an increase in the thermal efficiencies of SAHs. Some materials, used inside the collectors as a matrix, are scrap iron, wire mesh screen, aluminum, copper, broken glass pieces, and gravels. Chouksey and Sharma [18] theoretically investigated the performance of SAH packed with blackened wire screen matrices. They validated their theoretical results with the available experiments. The results of an analytical and experimental investigation of a new SAH with latent storage collector using spherical capsules as a packed bed absorber by Bouadila et al. [19] demonstrated that the useful energy which can be used during the 11 hours of the off-sun time comes out to be $200 \mathrm{~W} / \mathrm{m}^{2}$. In addition, the daily energy efficiency varies between $32 \%$ and $45 \%$.

While the abovementioned studies concentrate on improving the thermal efficiency of GUC, the aspect of maximum heat loss occurring from the glazing cover is overlooked. To counter this problem, preheating the inlet air from the unglazed perforated plate in the UTC is proposed. The most popular UTC design is the unglazed solar air heater (USAH) which was developed during the 1990s by
Christensen et al. [20]. The results of their experiments indicated that the UTC achieves $70 \%$ cost reduction compared to the GUCs. In the last decade, various attempts have been made to modify these types of solar collectors to improve their thermal efficiencies. Kutscher et al. [21] indicated that wind effects are significant and only some selective surface absorbers will be effective in obtaining greater temperature rise in UTCs. A 2D computational fluid dynamic (CFD) study by Gunnewiek et al. [22] demonstrated that reverse flow is observed at a mass flow rate of less than $0.0125 \mathrm{~kg} / \mathrm{s}$; hence, mass flow rates equal to this and lower should be avoided. Further, the code is modified by considering the effect of wind velocity on the flow distribution of an unglazed transpired plate [23]. The effects of the thickness of the absorber plate, pitch between the holes and diameter of the perforations, were studied by Børvik et al. [24]. An experimental and numerical study on UTC [25] indicated that the effect of the conductivity of an unglazed cover plate is less on their thermal performance. Christensen et al. [26] experimentally investigated the effect of two different materials of absorber plates of two UTCs having the same thickness, aluminum, and styrene plastic. At low mass flow rates of up to $0.02 \mathrm{~kg} / \mathrm{s}$, the heat transfer from the plastic absorber plate to the air stream increases by $0.2 \%$ compared to the aluminum plate. Vaziri et al. [27] investigated the thermal performances of perforated glazed SAHs and an unglazed transpired solar air heater using Plexiglas as the glazing material. The maximum efficiency in the perforated glazed solar air heater was obtained as $85 \%$ compared to the unglazed transpired solar air heater where it was $50 \%$.

To the best of our knowledge, no experiments have been performed with the slit-glazed solar air heater (SGSAH). The main aim of this investigation was to determine the effect of different gap distances between the glazed slits and the bed heights of the collector on the thermal performance by varying the air mass flow rates. In the SGSAH system, air is preheated by passing through slit glazed similar to that 


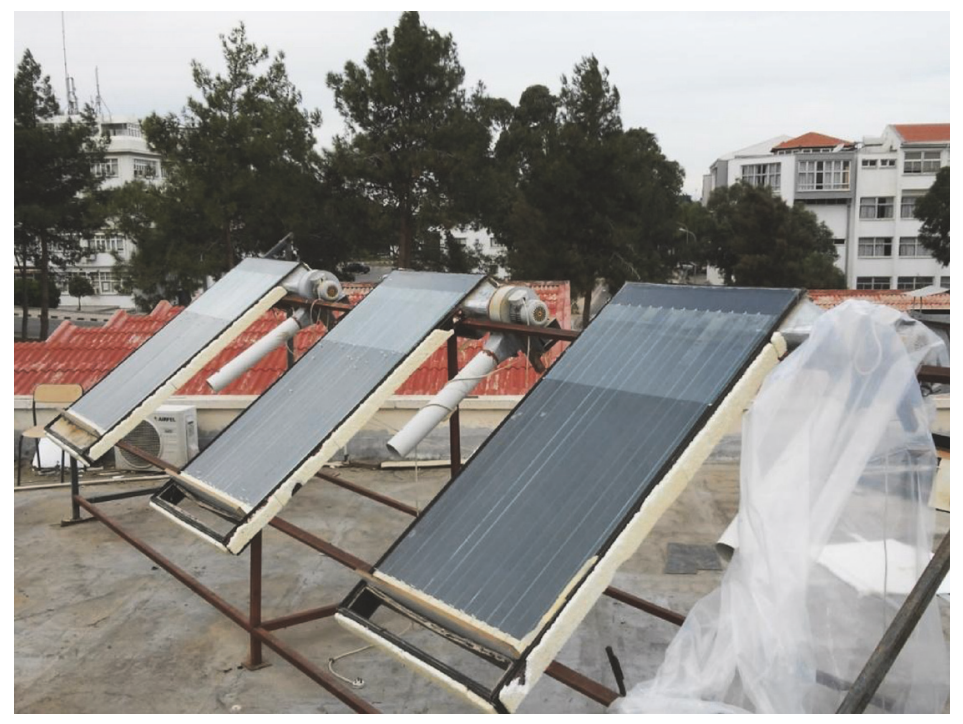

FIgURe 2: Pictorial view of the experimental setup of three slit-glazed solar air heaters.

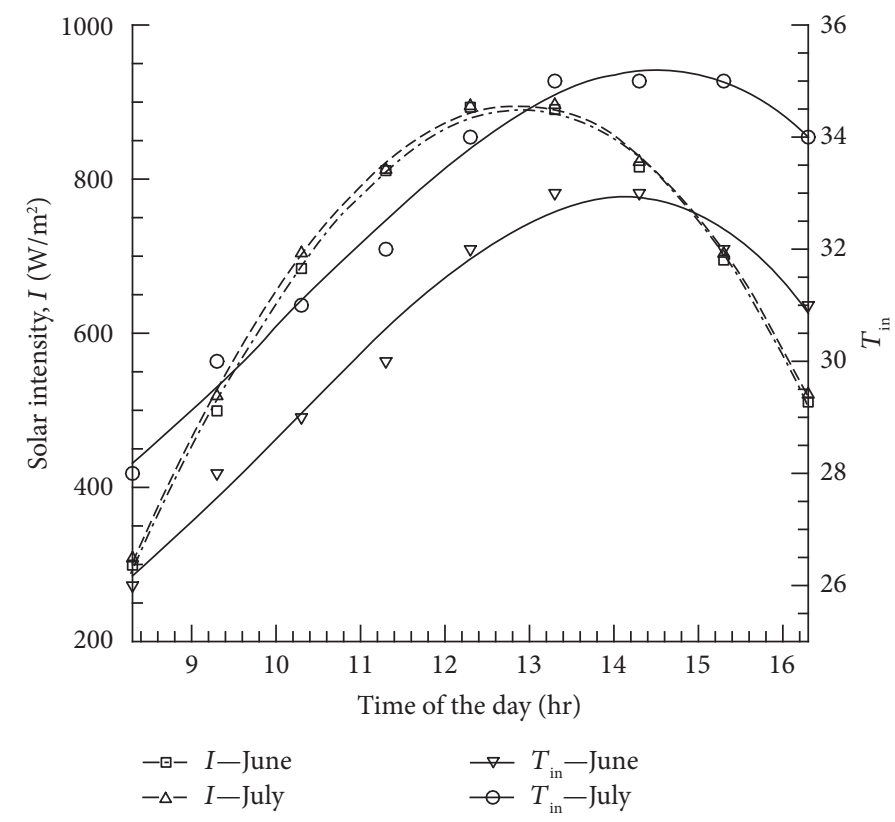

FIGURE 3: Mean hourly variation of solar intensity and ambient temperature.

as in the perforated glazed in the UTC. With this new design of SAH, advantages of both GUC and UTC can be combined, that is, having glass as the glazed cover and slit glazed as semitranspired, respectively, thereby improving the performance of SAHs.

A new design of the solar air heating system is proposed in order to minimize the heat losses from glazing. The aim of the study was to design, construct, and experimentally investigate slit-glazed solar air heaters with glass panes used as cover plates as they have many advantages over Plexiglas. Glass pane perforation is a costly process and prone to breakage (glass being fragile). To overcome this, air is withdrawn through the gaps between the glass panes rather than the circular perforations. In addition, the aim of this study is to construct a cheap and an efficient solar air heater with the same materials used as in a conventional SAH.

\section{Experimental Apparatus}

The experimental part was carried out between May 24, 2015, and July 10, 2015, with clear sky conditions at Famagusta $\left(35.125^{\circ} \mathrm{N}\right.$ and $33.95^{\circ} \mathrm{E}$ longitudes) in Cyprus from 8:30 am to $4: 30 \mathrm{pm}$ every day in intervals of one hour. The schematic view of the constructed SGSAH is shown in Figure 1.

Three SGSAHs were constructed and tested for thermal efficiency. The frames of the collectors were made from plywood with length, width, and thickness measuring $154 \mathrm{~cm}$, $91 \mathrm{~cm}$, and $1.5 \mathrm{~cm}$, respectively, and painted in matte black. 


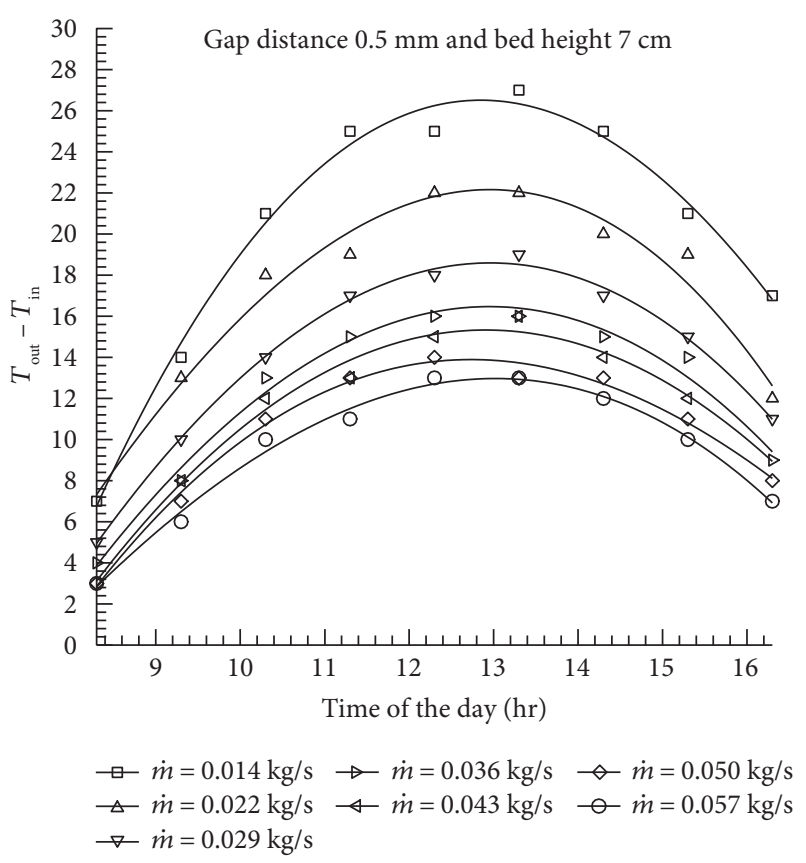

(a)

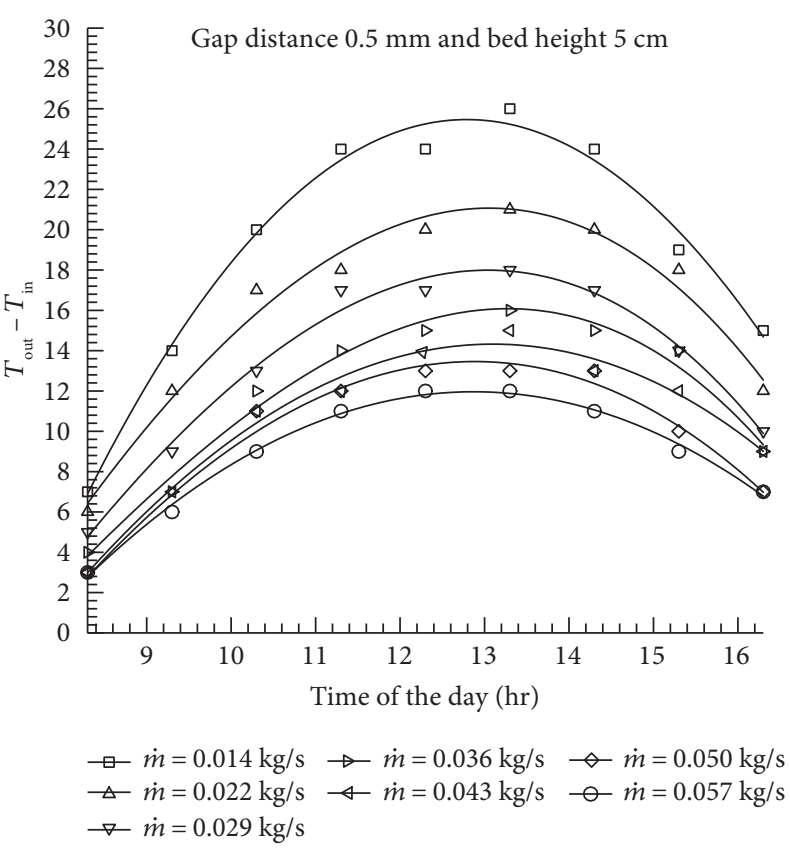

(b)



(c)

FIgURE 4: Temperature rise $\left(T_{\text {out }}-T_{\text {in }}\right.$ ) versus time at a gap distance of $0.5 \mathrm{~mm}$ for different mass flow rates $\dot{m}$ and three different bed heights (a) $7 \mathrm{~cm}$, (b) $5 \mathrm{~cm}$, and (c) $3 \mathrm{~cm}$.

The bed heights for the three SGSAHs were $3 \mathrm{~cm}, 5 \mathrm{~cm}$, and $7 \mathrm{~cm}$. The absorber plates of the collectors were made $1 \mathrm{~mm}$ thick of low carbon steel metal sheet and painted in matte black. Normal window glass panes, $4 \mathrm{~mm}$ in thickness, were used as glazing with length and width of each pane being $154 \mathrm{~cm}$ and $6 \mathrm{~cm}$, respectively. In order to reduce heat losses, the sides and bottom of the collectors were insulated by $3 \mathrm{~cm}$ thick Styrofoam. A $4 \mathrm{~mm}$ thick glass, $91 \mathrm{~cm}$ wide and $23 \mathrm{~cm}$ long, was placed at the top of the collector to ensure uniformity in flow and prevent any flow reversals. Figure 2 shows the pictorial view of the three constructed SGSAHs. The experiments were conducted for four different gaps between the panes, namely, $0.5 \mathrm{~mm}, 1.0 \mathrm{~mm}, 2.0 \mathrm{~mm}$, and $3 \mathrm{~mm}$, and mass fluxes were chosen as $0.014 \mathrm{~kg} / \mathrm{s}, 0.022 \mathrm{~kg} / \mathrm{s}$, $0.029 \mathrm{~kg} / \mathrm{s}, 0.036 \mathrm{~kg} / \mathrm{s}, 0.043 \mathrm{~kg} / \mathrm{s}, 0.050 \mathrm{~kg} / \mathrm{s}$, and $0.057 \mathrm{~kg} / \mathrm{s}$.

For each SGSAH, two type $\mathrm{T}$ thermocouples were employed to measure the inlet and outlet air temperatures and the temperatures at different points on the glazing. 


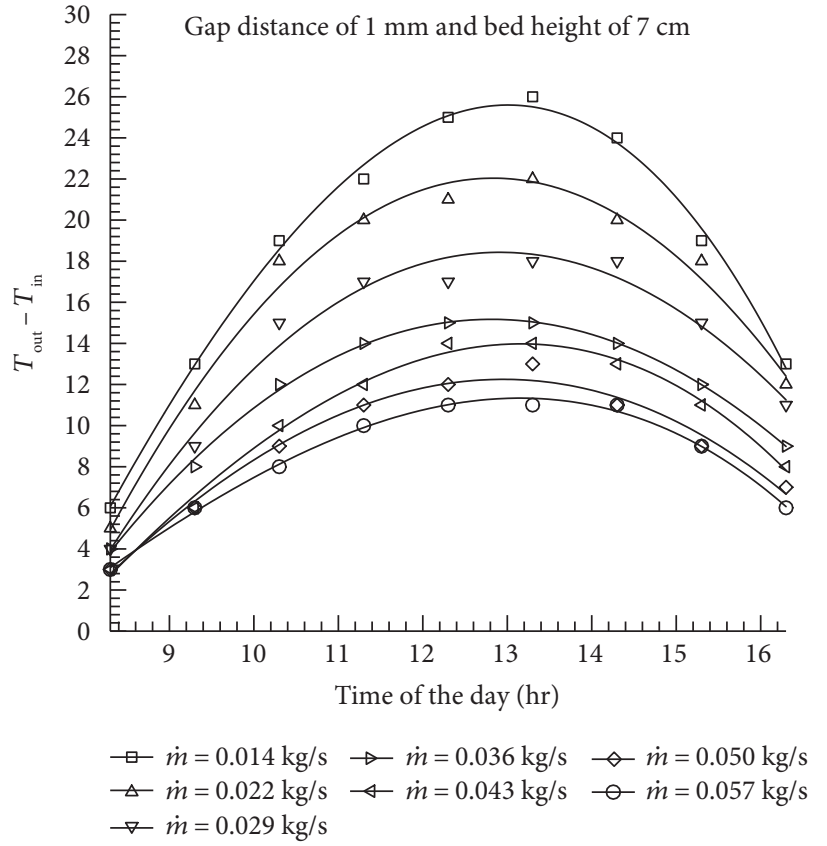

(a)

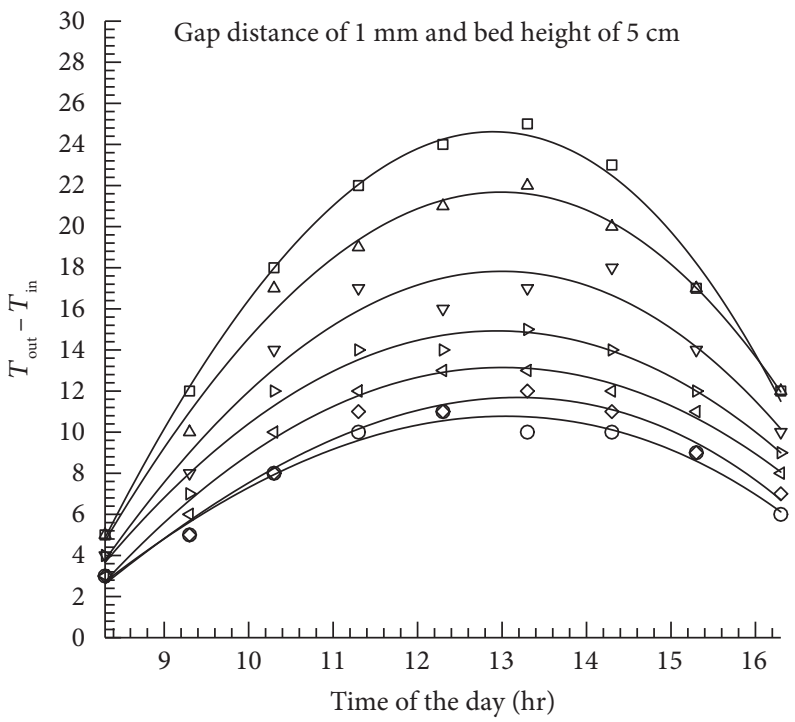

$\square \dot{m}=0.014 \mathrm{~kg} / \mathrm{s} \rightarrow \dot{m}=0.036 \mathrm{~kg} / \mathrm{s} \multimap \dot{m}=0.050 \mathrm{~kg} / \mathrm{s}$
$\triangle \dot{m}=0.022 \mathrm{~kg} / \mathrm{s} \multimap \dot{m}=0.043 \mathrm{~kg} / \mathrm{s} \multimap \dot{m}=0.057 \mathrm{~kg} / \mathrm{s}$
$\neg \dot{m}=0.029 \mathrm{~kg} / \mathrm{s}$

(b)

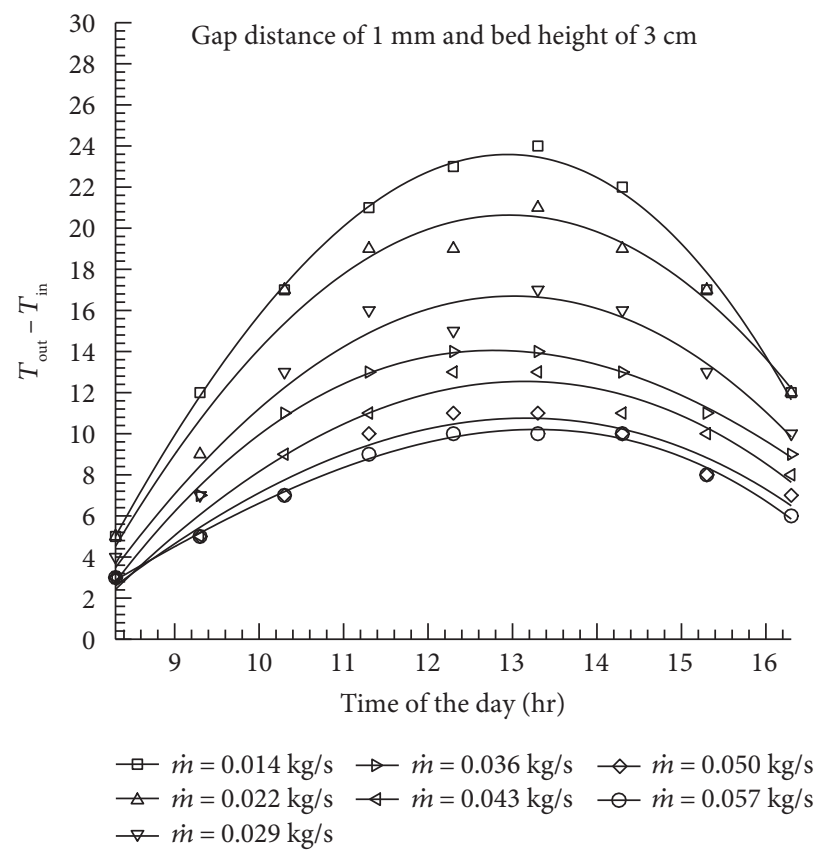

(c)

Figure 5: Temperature rise $\left(T_{\text {out }}-T_{\text {in }}\right.$ ) versus time at a gap distance of $1 \mathrm{~mm}$ for different mass flow rates $\dot{m}$ and three different bed heights (a) $7 \mathrm{~cm}$, (b) $5 \mathrm{~cm}$, and (c) $3 \mathrm{~cm}$.

Two-channel digital thermometers with an accuracy of $\pm 1^{\circ} \mathrm{C}$ were used to measure temperatures hourly during the day. Solar intensity was measured using an Eppley Radiometer Pyranometer (PSP) with a solar radiation meter model HHM1A digital Omega with $0.25 \%$ basic DC accuracy and a resolution of $\pm 0.5 \%$ having a range from 0 to $2800 \mathrm{~W} / \mathrm{m}^{2}$. The air velocity was measured using an Extech 407112 Vane anemometer. For the range of $0.4-10 \mathrm{~m} / \mathrm{s}$, the reading accuracy and data resolution were $0.2 \mathrm{~m} / \mathrm{s} \pm 2 \%$ and
$0.01 \mathrm{~m} / \mathrm{s}$, respectively. A dimmer switch was used to control the air flow rate in each collector. The collectors were oriented towards south to capture maximum irradiance and inclined at $39^{\circ}$ due to the geographical location of Cyprus.

In this study, efficiency is defined as follows:

$$
\eta=\frac{\dot{m} C_{p} \Delta T}{A_{c} I}
$$




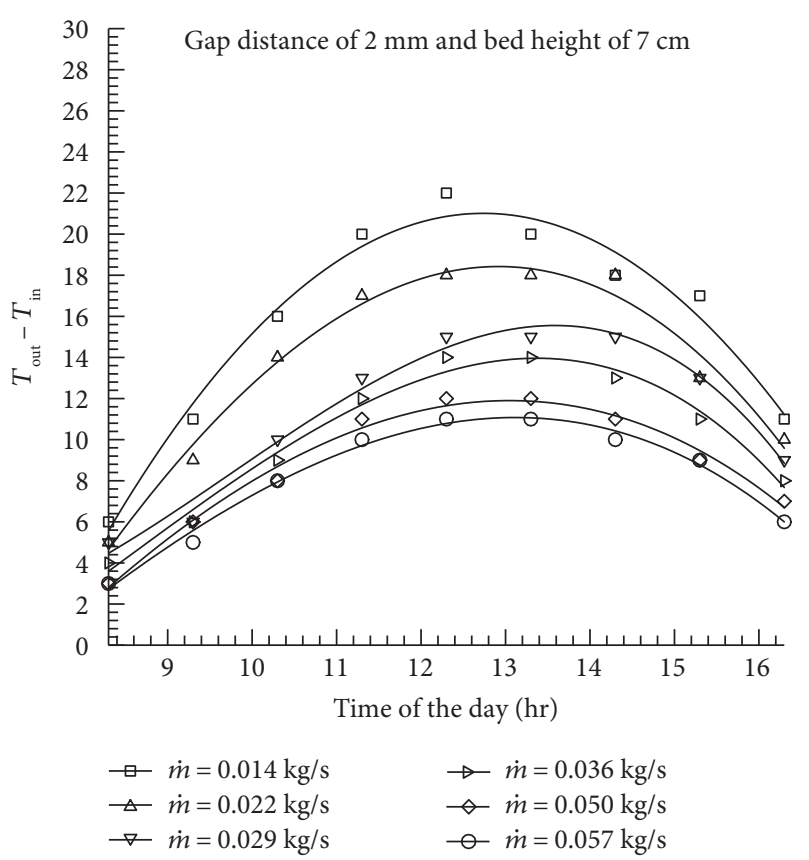

(a)

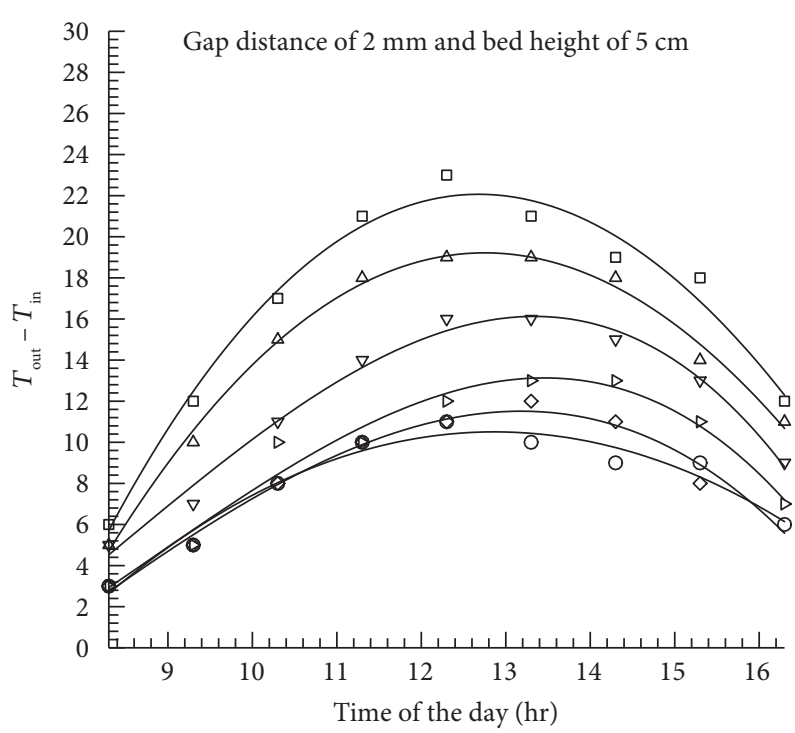

$\begin{array}{ll}\rightarrow \dot{m}=0.014 \mathrm{~kg} / \mathrm{s} & \rightarrow \dot{m}=0.036 \mathrm{~kg} / \mathrm{s} \\ \triangle \dot{m}=0.022 \mathrm{~kg} / \mathrm{s} & \multimap \dot{m}=0.050 \mathrm{~kg} / \mathrm{s} \\ \rightarrow \dot{m}=0.029 \mathrm{~kg} / \mathrm{s} & \multimap \dot{m}=0.057 \mathrm{~kg} / \mathrm{s}\end{array}$

(b)

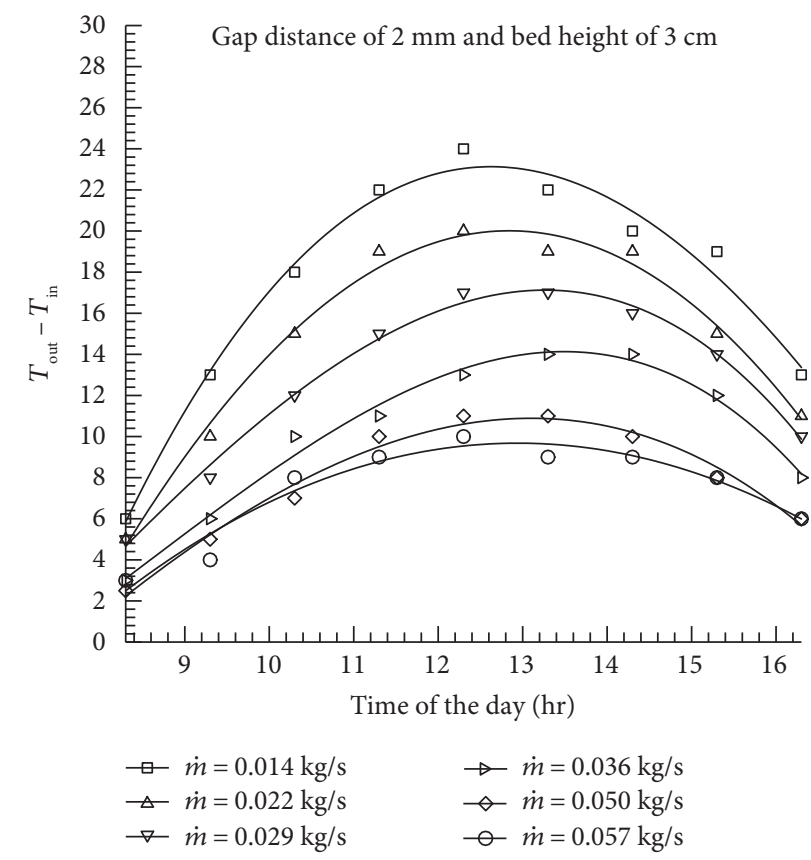

(c)

FIgURE 6: Temperature rise $\left(T_{\text {out }}-T_{\text {in }}\right)$ versus time at a gap distance of $2 \mathrm{~mm}$ for different mass flow rates $\dot{m}$ and three different bed heights (a) $7 \mathrm{~cm}$, (b) $5 \mathrm{~cm}$, and (c) $3 \mathrm{~cm}$.

where $\dot{m}$ is the mass flow rate, $C_{p}$ is the specific heat of air, $\Delta T$ is the temperature difference between the inlet and outlet of air, $A_{c}$ is the surface area of collector, and $I$ is the solar intensity.

\section{Uncertainty Evaluation}

In this section, the uncertainty of the air mass flow rate and thermal efficiency are discussed. The mass flow rate is determined as follows:

$$
\dot{m}=\rho V A,
$$

where $\rho$ is the air density, $V$ is the outlet air velocity, and $A$ is the cross-sectional area of the outlet. The fractional uncertainty, $\omega_{\dot{m}} / \dot{m}$, for the air mass flow rate can be calculated as follows [28]:

$$
\frac{\omega_{\dot{m}}}{\dot{m}}=\left[\left(\frac{\omega_{T_{\text {air }}}}{T_{\text {air }}}\right)^{2}+\left(\frac{\omega_{V}}{V}\right)^{2}+4\left(\frac{\omega_{r}}{r}\right)^{2}\right]^{1 / 2},
$$




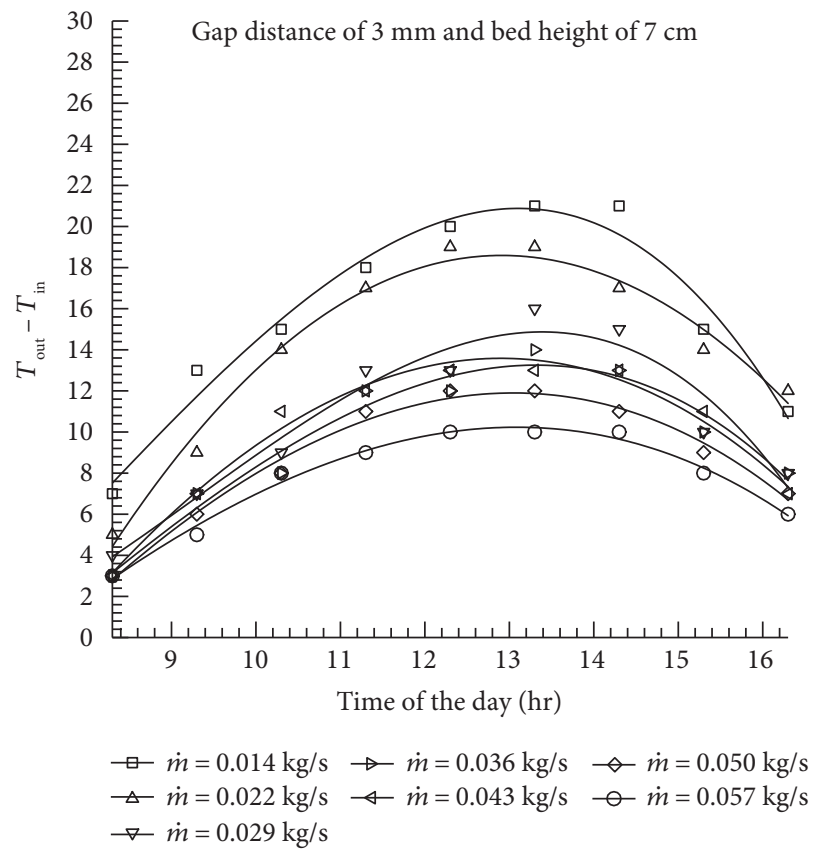

(a)

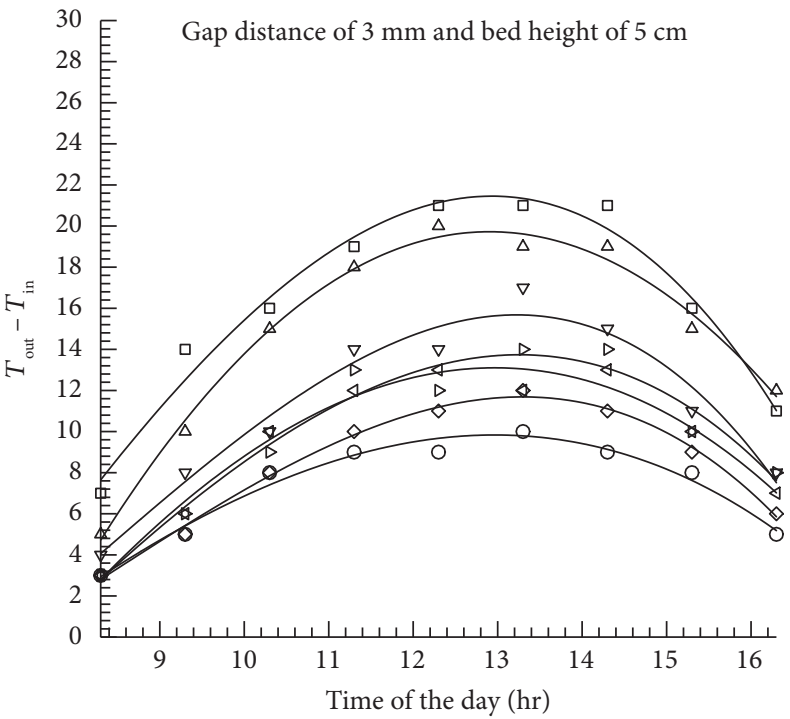

$\square \dot{m}=0.014 \mathrm{~kg} / \mathrm{s} \rightarrow \dot{m}=0.036 \mathrm{~kg} / \mathrm{s} \multimap \dot{m}=0.050 \mathrm{~kg} / \mathrm{s}$
$\triangle \dot{m}=0.022 \mathrm{~kg} / \mathrm{s} \multimap \dot{m}=0.043 \mathrm{~kg} / \mathrm{s} \multimap \dot{m}=0.057 \mathrm{~kg} / \mathrm{s}$
$\neg \dot{m}=0.029 \mathrm{~kg} / \mathrm{s}$

(b)



(c)

FIgURE 7: Temperature rise $\left(T_{\text {out }}-T_{\text {in }}\right)$ versus time at a gap distance of $3 \mathrm{~mm}$ for different mass flow rates $\dot{m}$ and three different bed heights (a) $7 \mathrm{~cm}$, (b) $5 \mathrm{~cm}$, and (c) $3 \mathrm{~cm}$.

where $T_{\text {air }}$ is the average temperature between the inlet and outlet and $r$ is the pipe radius of the air outlet.

The fractional uncertainty in the efficiency can be found as follows:

$$
\frac{\omega_{\eta}}{\eta}=\left[\left(\frac{\omega_{\dot{m}}}{\dot{m}}\right)^{2}+\left(\frac{\omega_{\Delta T}}{\Delta T}\right)^{2}+\left(\frac{\omega_{I}}{I}\right)^{2}\right]^{1 / 2} .
$$

The uncertainties within the mass flow rate and thermal efficiency for the highest air mass flow rate were calculated to be $1.45 \%$ and $3.7 \%$, respectively.

\section{Results}

4.1. Variation of Solar Intensity and Ambient Temperature with Time. Figure 3 shows the mean hourly variation of solar 


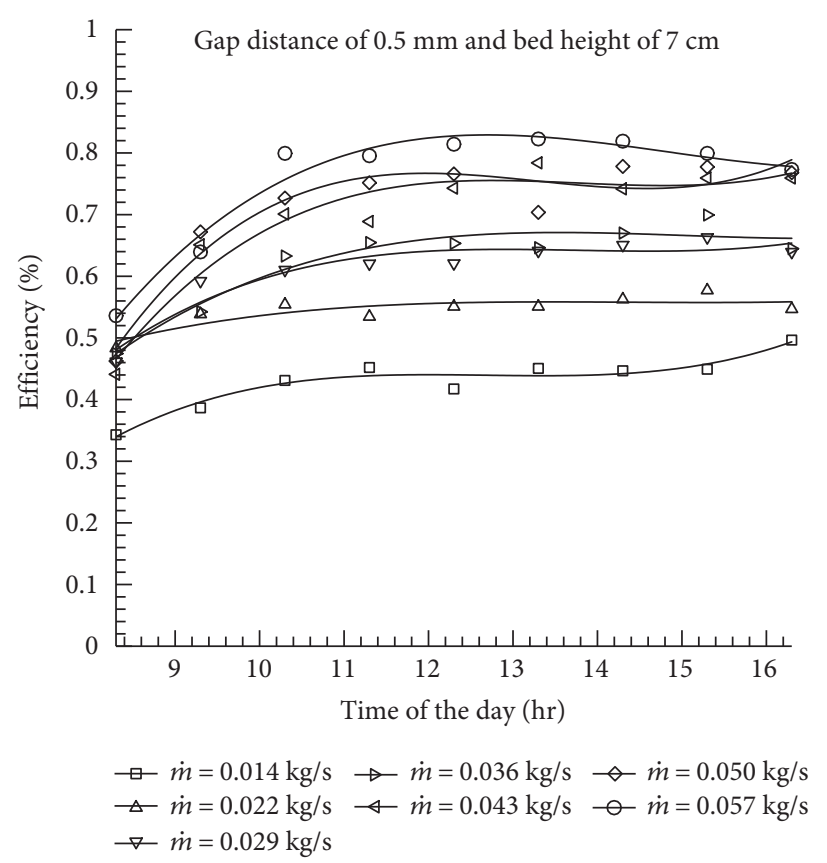

(a)

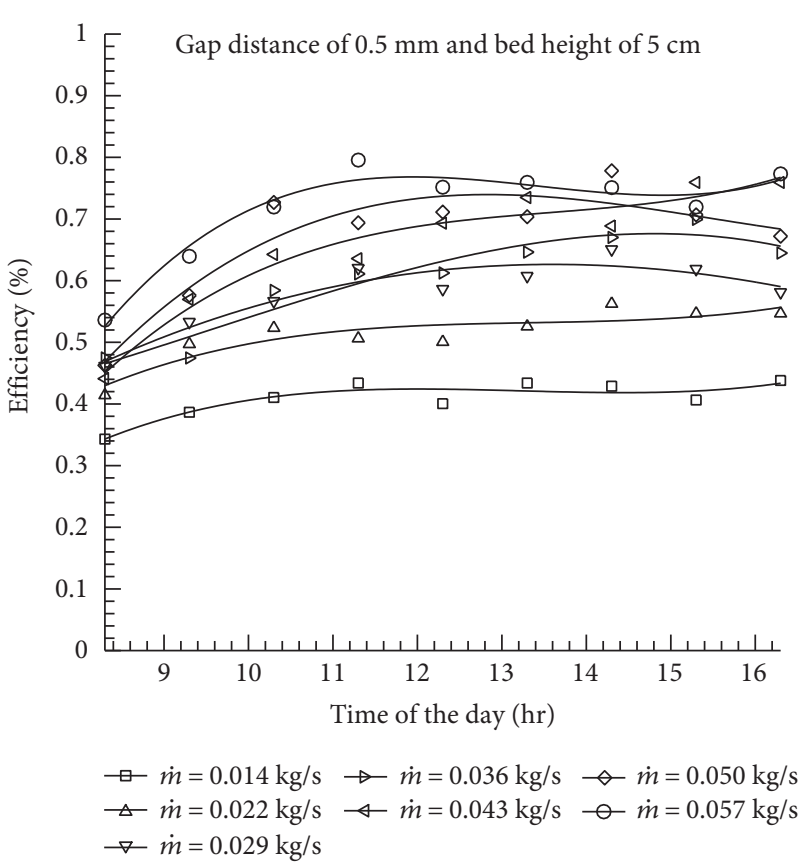

(b)

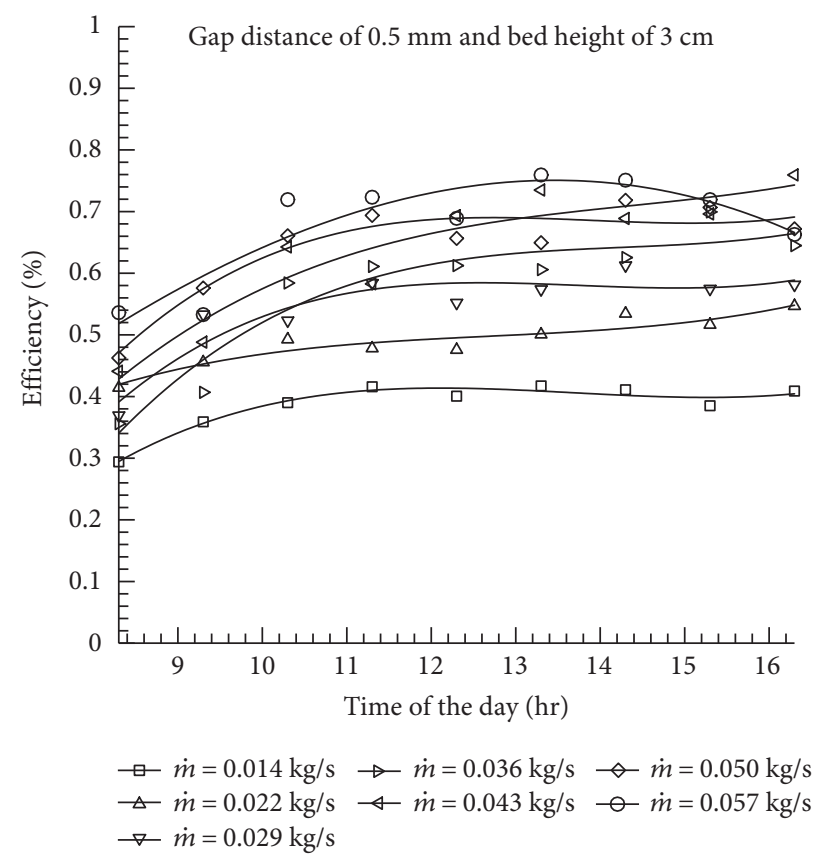

(c)

Figure 8: Thermal efficiency versus time at the gap distance of $0.5 \mathrm{~mm}$ for bed heights (a) $7 \mathrm{~cm}$, (b) $5 \mathrm{~cm}$, and (c) $3 \mathrm{~cm}$ and different mass flux rates.

radiation and ambient temperature. The solar intensity increased steadily during the morning hours reaching to a peak value at midday and then reduced gradually until sunset. The behavior was, by and large, consistent during the entire course of the measurements. The ambient temperature increased during the day until afternoon and reduced briefly thereafter. During the experiments, the highest value of the solar intensity was measured as $896 \mathrm{~W} / \mathrm{m}^{2}$ with average value coming out to be $682 \mathrm{~W} / \mathrm{m}^{2}$ and the maximum ambient temperature $\left(T_{\text {in }}\right)$ was recorded at $35^{\circ} \mathrm{C}$ with the average value being $31^{\circ} \mathrm{C}$.

4.2. The Temperature Rise $\left(\Delta T=T_{\text {out }}-T_{\text {in }}\right)$ as a Function of Time. The variations of $\Delta T$ versus standard local time of the day time for different gap distances, bed heights, and mass fluxes are demonstrated in Figures 4-7.

For a gap distance of $0.5 \mathrm{~mm}$ (Figures 4(a), 4(b), and $4(\mathrm{c}))$, the $\Delta T$ for different mass flow rates increased during 


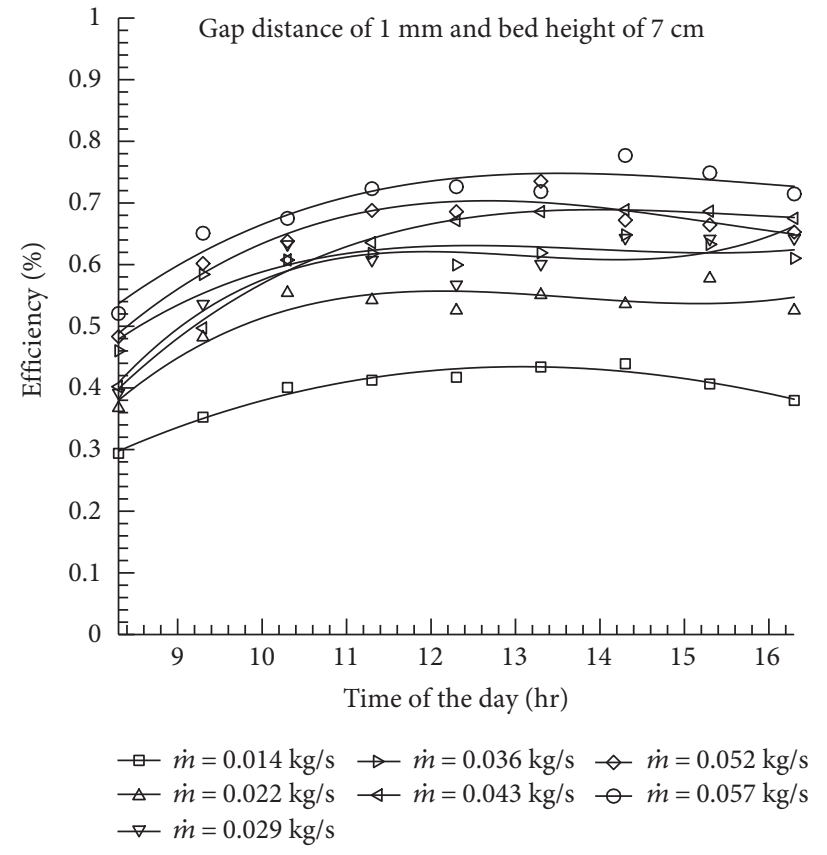

(a)

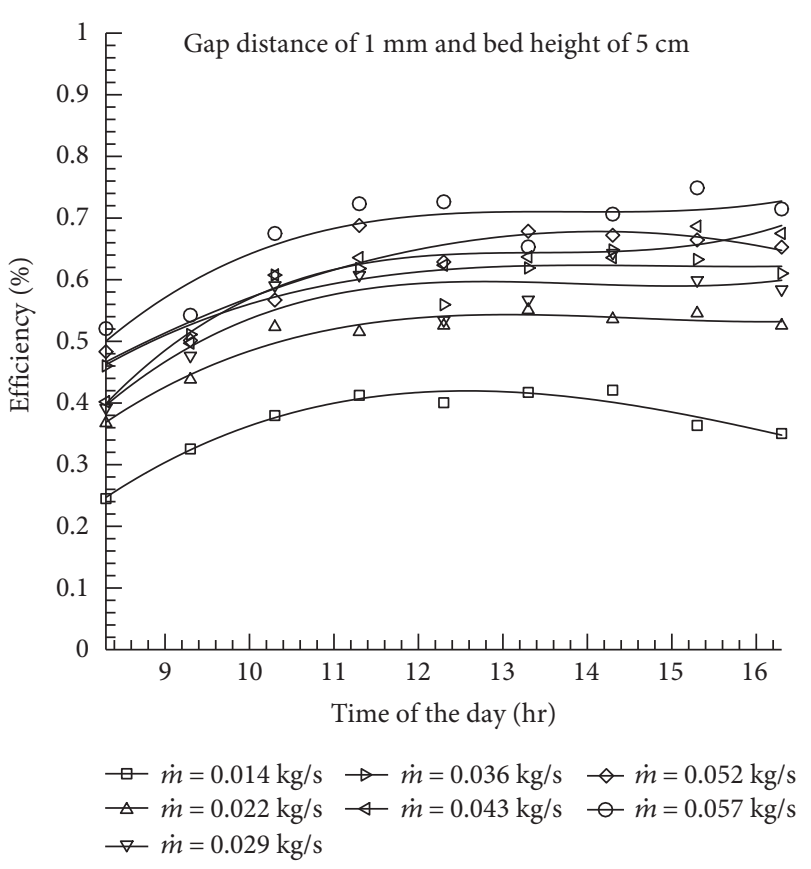

(b)

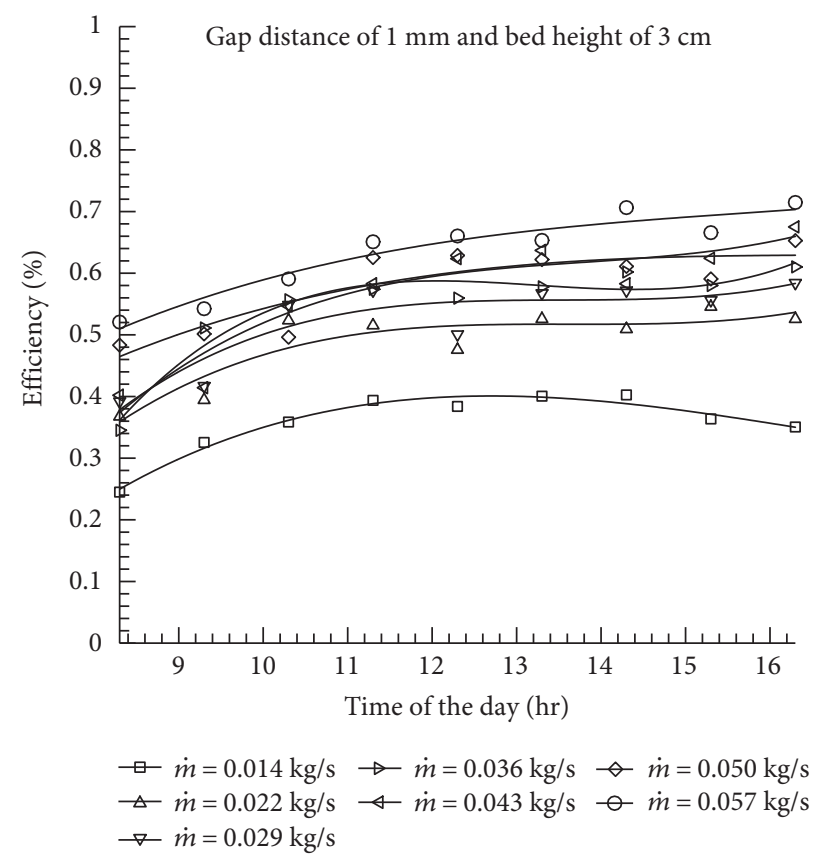

(c)

Figure 9: Thermal efficiency versus time at the gap distance of $1 \mathrm{~mm}$ for bed heights (a) $7 \mathrm{~cm}$, (b) $5 \mathrm{~cm}$, and (c) $3 \mathrm{~cm}$ and different mass flux rates.

the morning hours reached maximum between 12:00 and 13:00 and then decreased until sunset. For different bed heights, $3 \mathrm{~cm}, 5 \mathrm{~cm}$, and $7 \mathrm{~cm}$, the maximum values of $\Delta T$ were obtained as $25^{\circ} \mathrm{C}, 26^{\circ} \mathrm{C}$, and $27^{\circ} \mathrm{C}$, respectively, for the least value of mass flux $(0.014 \mathrm{~kg} / \mathrm{s})$. The inlet velocity at a smaller gap distance is higher compared with the inlet velocity of a bigger gap distance. As friction increases at a lower gap distance, the inlet air contact area with glass panes also increases. Therefore, convective and radiation losses decrease at smaller gap distances. Higher inlet velocity increases gain in heat convection energy from the glass panes. Therefore, it is expected to have higher $\Delta T$ at a lower gap distance. There is also more possibility for a reversal flow in a higher gap distance for SAH.

On increasing the gap distance to $1 \mathrm{~mm}$, the maximum $\Delta T^{\circ}$ s were achieved as $24^{\circ} \mathrm{C}, 25^{\circ} \mathrm{C}$, and $26^{\circ} \mathrm{C}$ for the bed heights of $3 \mathrm{~cm}, 5 \mathrm{~cm}$, and $7 \mathrm{~cm}$, respectively, for the minimum mass flow rate (see Figures 5(a), 5(b), and 5(c)). 


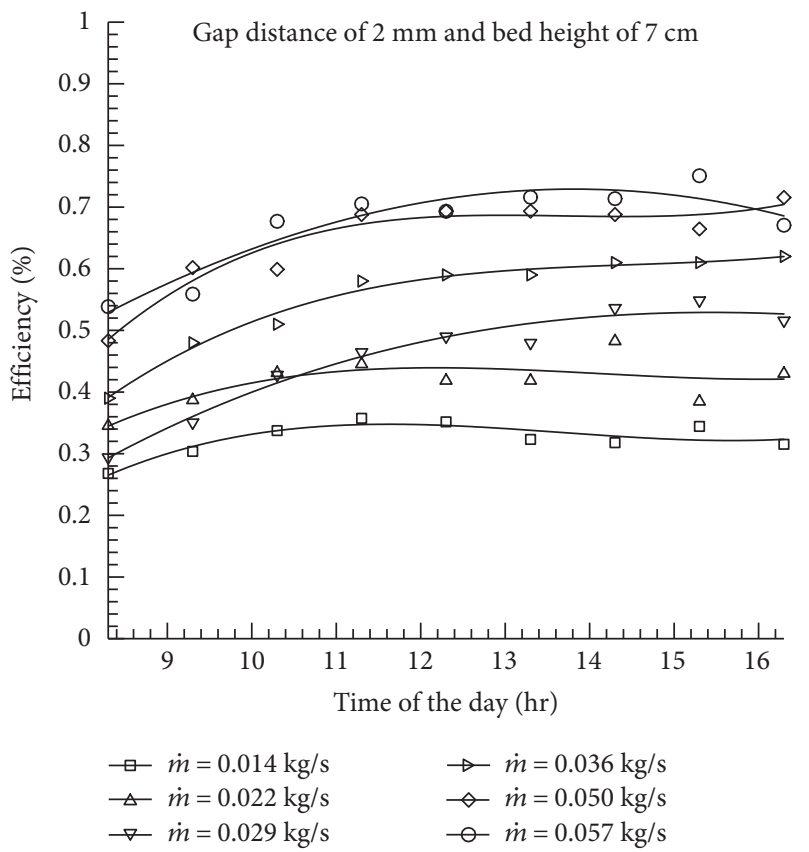

(a)

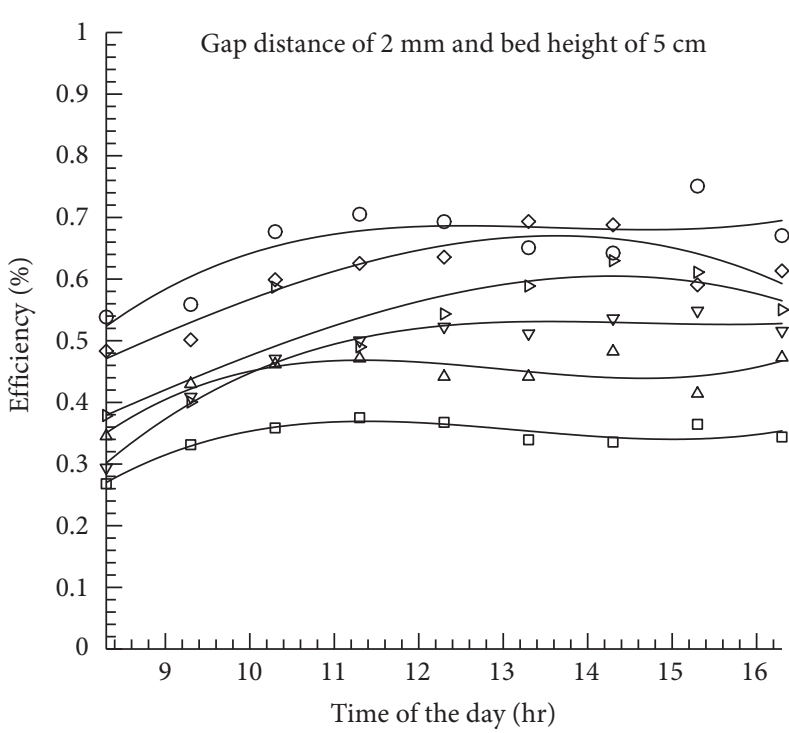

$\square \dot{m}=0.014 \mathrm{~kg} / \mathrm{s}$
$\triangle \quad \dot{m}=0.022 \mathrm{~kg} / \mathrm{s}$
$\square \quad \dot{m}=0.029 \mathrm{~kg} / \mathrm{s}$

$\rightarrow \dot{m}=0.036 \mathrm{~kg} / \mathrm{s}$

$\diamond \dot{m}=0.050 \mathrm{~kg} / \mathrm{s}$

○- $\dot{m}=0.057 \mathrm{~kg} / \mathrm{s}$

(b)



(c)

FIGURE 10: Thermal efficiency versus time at the gap distance of $2 \mathrm{~mm}$ for bed heights (a) $7 \mathrm{~cm}$, (b) $5 \mathrm{~cm}$, and (c) $3 \mathrm{~cm}$ and different mass flux rates.

However, on increasing the gap distances to $2 \mathrm{~mm}$ and $3 \mathrm{~mm}$, the maximum $\Delta T^{\prime} \mathrm{s}\left(23^{\circ} \mathrm{C}\right.$ and $22.5^{\circ} \mathrm{C}$, resp.) were achieved in the SGSAH with the lowest values of bed height $(3 \mathrm{~cm})$ and mass flux rates $(0.014 \mathrm{~kg} / \mathrm{s})$. These $\Delta T$ values were low compared to the smaller gap distance values.

The experimental findings revealed the following:

(a) For lower mass fluxes $(0.014-0.036 \mathrm{~kg} / \mathrm{s})$, (i) for wider gaps $(2 \mathrm{~mm}$ and $3 \mathrm{~mm})$, higher temperature differences were obtained in the SGSAH with lesser bed heights $(3 \mathrm{~cm})$ and (ii) for smaller gaps $(0.5 \mathrm{~mm}$ and $1 \mathrm{~mm}$ ), higher temperature differences were obtained for greater bed heights, that is, $7 \mathrm{~cm}$. The highest value of $\Delta T\left(27^{\circ} \mathrm{C}\right)$ was obtained for a gap distance of $0.5 \mathrm{~mm}$, lowest mass flow rate of $0.014 \mathrm{~kg} / \mathrm{s}$, and bed height of $7 \mathrm{~cm}$. The highest $\Delta T$ values (for any bed height) gradually decreased on increasing the gap distances from $0.5 \mathrm{~mm}$ to $3 \mathrm{~mm}$. Therefore, for low mass fluxes, the performance of the SGSAH with $3 \mathrm{~cm}$ bed height was higher than that of the other two SGSAHs 


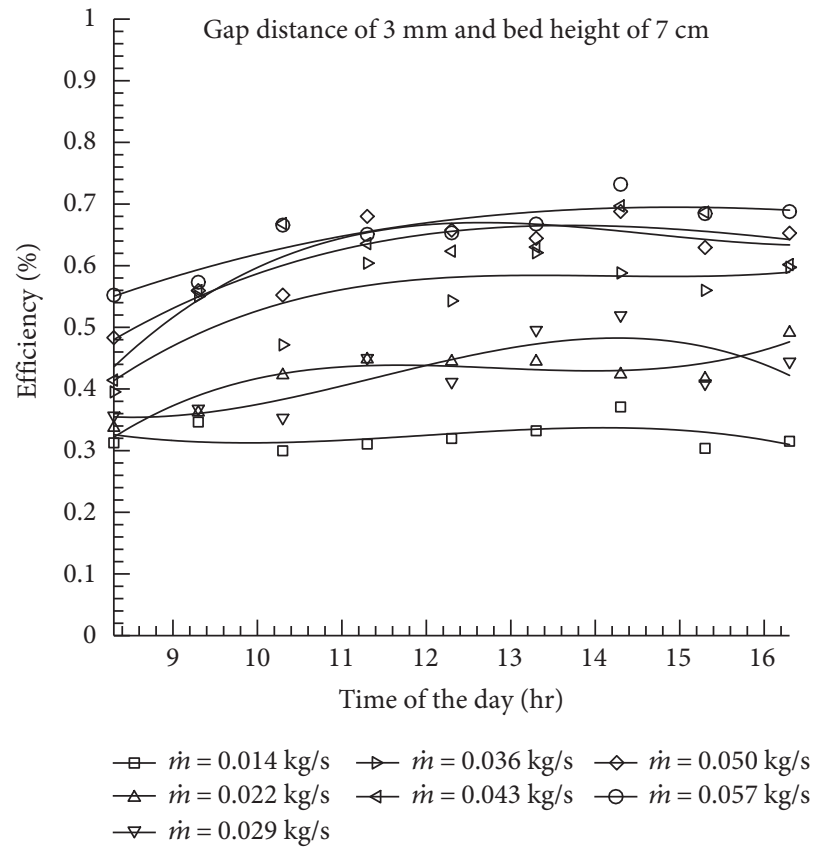

(a)

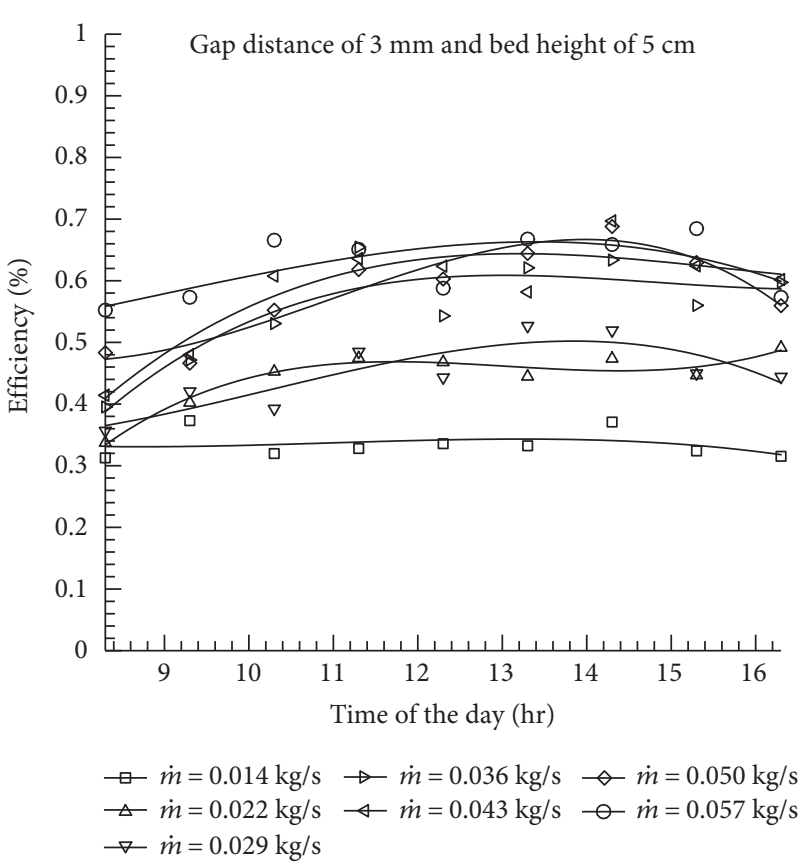

(b)

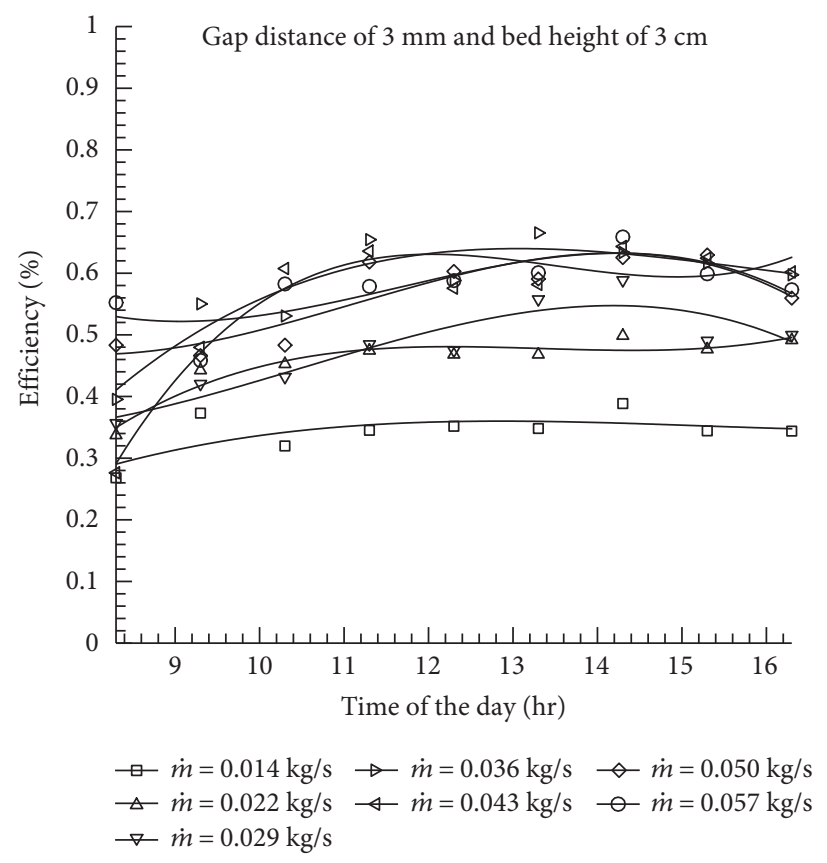

(c)

FIGURE 11: Thermal efficiency versus time at the gap distance of $3 \mathrm{~mm}$ for bed heights (a) $7 \mathrm{~cm}$, (b) $5 \mathrm{~cm}$, and (c) $3 \mathrm{~cm}$ and different mass flux rates.

at wider gaps and the SGSAH with $7 \mathrm{~cm}$ bed height performed better than the others for smaller gaps.

(b) For higher mass fluxes $(0.043-0.057 \mathrm{~kg} / \mathrm{s})$, the SGSAH with bed height $7 \mathrm{~cm}$ showed higher temperature differences at both smaller and wider gaps compared with other SGSAHs (Figures 4-7).

Air inlet through the gap between the panes continues to gain energy from an absorber plate by heat convection inside the plenum. There is a possibility that at low mass flow rates and higher bed heights, the working fluid may not fully come in contact with the lower portion of the absorber plate.

\subsection{Thermal Efficiency as a Function of Time.}

(a) For a gap distance of $0.5 \mathrm{~mm}$, the maximum efficiency was obtained as $82 \%$ in the SGSAH with a bed height of $7 \mathrm{~cm}$ and a maximum mass flux of $0.057 \mathrm{~kg} / \mathrm{s}$ 


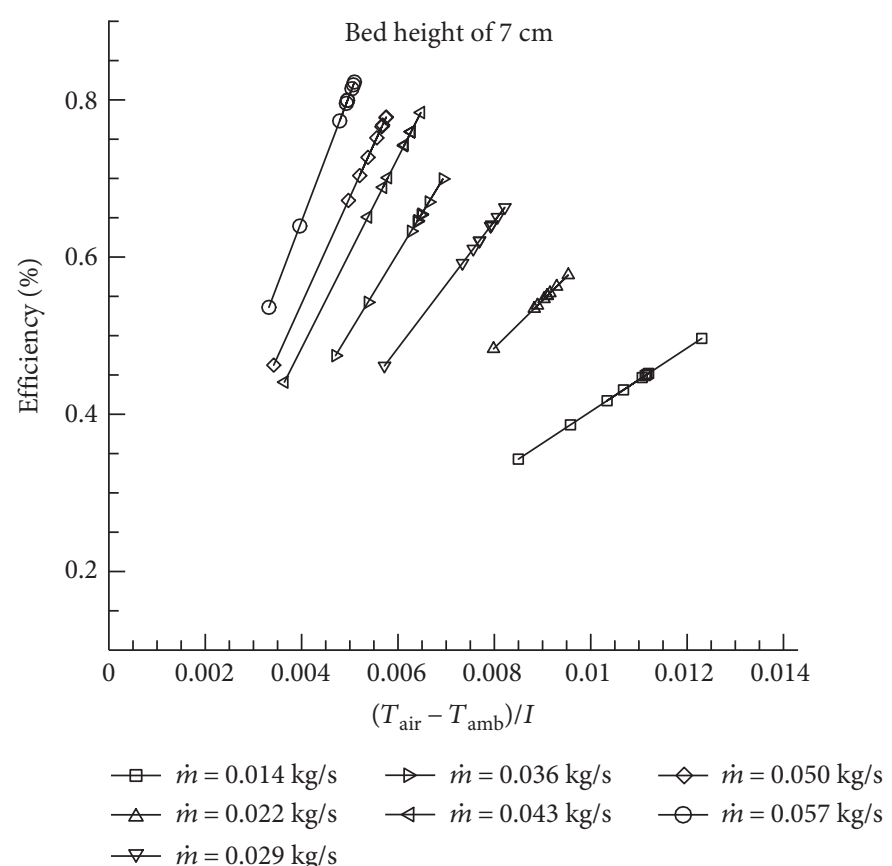

(a)



(b)

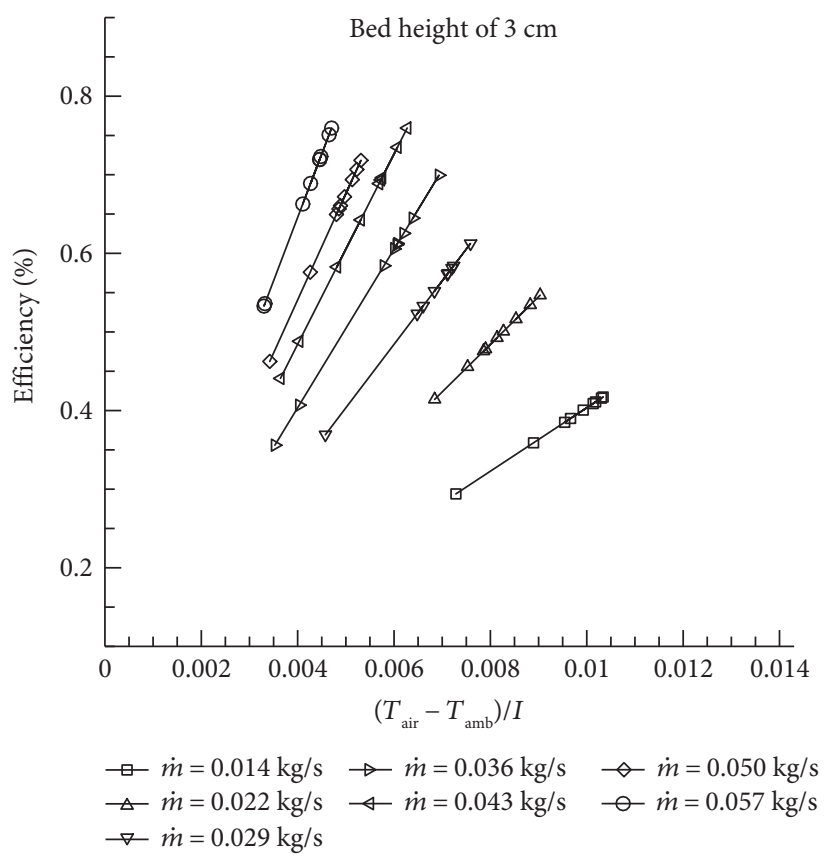

(c)

FiguRE 12: Efficiency versus $\left(T_{\text {air }}-T_{\text {amb }}\right) / I$ at a gap distance of $0.5 \mathrm{~mm}$ and different mass fluxes for SGSAHs with varying bed heights (a) $7 \mathrm{~cm}$, (b) $5 \mathrm{~cm}$ and (c) $3 \mathrm{~cm}$.

(Figure 8(a)). The maximum thermal efficiencies of SGSAHs having bed heights of $5 \mathrm{~cm}$ and $3 \mathrm{~cm}$ were found to be $79 \%$ and $75 \%$, respectively (Figures $8(\mathrm{~b})$ and $8(\mathrm{c})$ ). In addition, the average efficiencies for the SGSAHs with bed heights of $7 \mathrm{~cm}, 5 \mathrm{~cm}$, and $3 \mathrm{~cm}$ were found to be $62 \%$, $59 \%$, and $56 \%$, respectively. Hence, the highest value of thermal efficiency for SGSAH with a
$0.5 \mathrm{~mm}$ gap distance was found with a bed height of $7 \mathrm{~cm}$ for all the mass fluxes.

(b) By increasing the gap distance to $1 \mathrm{~mm}$, the maximum thermal efficiency was achieved for the SGSAH with a bed height of $7 \mathrm{~cm}$ as $77 \%$ with the mass flux as $0.057 \mathrm{~kg} / \mathrm{s}$ (Figure 9(a)). The average efficiencies for different bed heights, $7 \mathrm{~cm}, 5 \mathrm{~cm}$ and $3 \mathrm{~cm}$, were 
$57 \%$, 55\%, and 52\%, respectively (Figures 9(a), 9(b), and $9(\mathrm{c})$ ). This showed an overall decrease in the maximum thermal efficiency obtained for the gap distance of $0.5 \mathrm{~mm}$ from $82 \%$ to $77 \%$.

(c) As the gap distance was increased to $2 \mathrm{~mm}$, the maximum thermal efficiency was achieved as $75 \%$ with a bed height of $7 \mathrm{~cm}$ and a maximum mass flux of $0.057 \mathrm{~kg} / \mathrm{s}$ (Figure 10(a)). For all other mass fluxes with a bed height of $7 \mathrm{~cm}$, no maximum efficiency was found. The average thermal efficiencies were found to be $50 \%, 49 \%$, and $49 \%$ for bed heights of $7 \mathrm{~cm}, 5 \mathrm{~cm}$, and $3 \mathrm{~cm}$, respectively. The results also show that, for lower mass fluxes $(0.014-0.036 \mathrm{~kg} / \mathrm{s})$, the thermal performance of the SGSAH with $3 \mathrm{~cm}$ bed height was higher than that of the other two SGSAHs (Figures 10(a), 10(b), and 10(c)). The maximum efficiency further reduced as the gap distance increased, from $77 \%$ in $1 \mathrm{~mm}$ case to $75 \%$ here.

(d) It is found that the thermal efficiency is significantly dependent on the ambient temperature and it enhances with increasing ambient temperature. In the morning when the ambient temperature is low, the amount of heat losses are higher from the collectors to the environment compared to the afternoon.

(e) For $3 \mathrm{~mm}$ gap distance, the maximum thermal efficiency decreased further (compared to smaller gap distances) to $73 \%$ in the SGSAH with a bed height of $7 \mathrm{~cm}$ and a mass flux of $0.057 \mathrm{~kg} / \mathrm{s}$ (Figure $11(\mathrm{a})$ ). The average thermal efficiencies were obtained as $50 \%$ for each of the SGSAH. Also, it is found that the thermal efficiency is significantly dependent on the ambient temperature and it increased with the increase of the ambient temperature. In the morning when ambient temperature is low, the amount of heat losses are higher from the collectors to the environment in the morning in comparison with the afternoon.

4.4. Efficiency versus $\left(T_{\mathrm{air}}-T_{\mathrm{amb}}\right) / I$. Figures $12(\mathrm{a}), 12(\mathrm{~b})$, and 12 (c) show the efficiency versus $\left(T_{\text {air }}-T_{\text {amb }}\right) / I$ plot with different mass fluxes for three different bed heights and for a gap distance of $0.5 \mathrm{~mm}$. The thermal efficiency of the SGSAHs increased as the $\left(T_{\mathrm{air}}-T_{\mathrm{amb}}\right) / I$ ratio increased steeply for higher mass fluxes than that for lower mass flux rates. Also, the thermal efficiencies increased with increasing mass fluxes, as expected. Similar results were obtained in earlier studies [27, 29, 30]. The maximum efficiency was obtained for the bed height of $7 \mathrm{~cm}$ with maximum mass flux. The observations were made for different gap distances which showed a similar pattern. Here, the results related to the most efficient gap distance, $0.5 \mathrm{~mm}$, are presented.

\section{Conclusions}

The performances of three different SGSAHs at various gap distances, mass fluxes, and bed heights were investigated experimentally in terms of the following observables: (i) solar intensity and ambient temperature, (ii) temperature rise of the outlet air, and (iii) thermal efficiency. A new design for SAHs was proposed in this study to minimize the glazing heat losses that are present in a conventional SAH.

The results indicated that by increasing mass flux, $\Delta T$ decreased while the thermal efficiency increased. At a minimum mass flow rate of $0.014 \mathrm{~kg} / \mathrm{s}$, a gap distance of $0.5 \mathrm{~mm}$, and a bed height of $7 \mathrm{~cm}$, the maximum $\Delta T$ was achieved to be $27^{\circ} \mathrm{C}$. The maximum efficiency of $82 \%$ was obtained for the bed height of $7 \mathrm{~cm}$ where the gap distance was minimum $(0.5 \mathrm{~mm})$ and the mass flux was the highest $(0.057 \mathrm{~kg} / \mathrm{s})$ which shows significant improvement on the thermal efficiency in comparison to the conventional SAHs varied between $28 \%$ and $40 \%$ [31]. The results for the gap distances $0.5 \mathrm{~mm}$ and $1 \mathrm{~mm}$ showed that the SGSAH with $7 \mathrm{~cm}$ bed height performed better compared to the other two SGSAHs for higher mass fluxes (i.e., above $0.043 \mathrm{~kg} / \mathrm{s}$ ). For the gap distances $2 \mathrm{~mm}$ and $3 \mathrm{~mm}$ at lower mass fluxes $(0.014-$ $0.043 \mathrm{~kg} / \mathrm{s})$, the thermal performance of the SGSAH with $3 \mathrm{~cm}$ bed height was higher than the other two SGSAHs. The efficiency of the SGSAH improved substantially after employing slit glazing compared to the conventional SAH.

\section{Nomenclature}

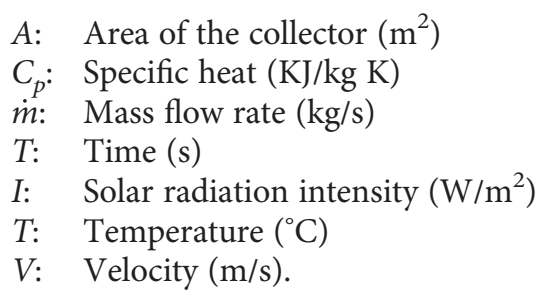

\section{Greek Symbols}

$\Delta T: \quad$ Temperature difference $\left(T_{\text {out }}-T_{\text {in }}\right)\left({ }^{\circ} \mathrm{C}\right)$

$\rho: \quad$ Density of air $\left(\mathrm{kg} / \mathrm{m}^{3}\right)$

$\mu: \quad$ Viscosity of air $\left(\mathrm{N} \mathrm{s} / \mathrm{m}^{2}\right)$

$\eta$ : $\quad$ Efficiency of the solar air heater $\left(\eta=\dot{m} C_{p} \Delta T / I A_{c}\right)$.

\section{Subscripts}

in: Inlet

out: Outlet

air: Film temperature.

\section{Abbreviations}

SAH: Solar air heater

SGSAH: Solar-glazed solar air heater

UTC: Unglazed transpired collector

GUC: Glazed untranspired collector.

\section{Conflicts of Interest}

The authors declare that there is no conflict of interest regarding the publication of this paper. 


\section{References}

[1] C. D. Ho, H. M. Yeh, T. W. Cheng, T. C. Chen, and R. C. Wang, "The influences of recycle on performance of baffled double-pass flat-plate solar air heaters with internal fins attached," Applied Energy, vol. 86, pp. 1470-1478, 2009.

[2] A. P. Omojaro and L. B. Y. Aldabbagh, "Experimental performance of single and double pass solar air heater with fins and steel wire mesh as absorber," Applied Energy, vol. 87, pp. 3759-3765, 2010.

[3] M. A. Wazed, Y. Nukman, and M. T. Islam, "Design and fabrication of a cost effective solar air heater for Bangladesh," Applied Energy, vol. 87, pp. 3030-3036, 2010.

[4] S. K. Das and A. Chakraverty, "Performance of a solar collector with different glazing materials and their degradation under the condition prevailing in a solar collector," Energy Conversion and Management, vol. 31, pp. 233-242, 1991.

[5] A. A. El-sebaii, S. Aboul-enein, M. R. I. Ramadan, S. M. Shalaby, and B. M. Moharram, "Thermal performance investigation of double pass-finned plate solar air heater," Applied Energy, vol. 88, pp. 1727-1739, 2011.

[6] G. Sugantharaj, K. Vijay, and K. Kulundaivel, "Performances of packed bed double pass solar air heater with different inclinations and transverse wire mesh with different intervals," Thermal Science, vol. 20, pp. 175-183, 2016.

[7] A. Priyam and P. Chand, "Thermal and thermohydraulic performance of wavy finned absorber solar air heater," Solar Energy, vol. 130, pp. 250-259, 2016.

[8] S. Skullong, P. Promvonge, C. Thianpong, and M. Pimsarn, "Thermal performance in solar air heater channel with combined wavy-groove and perforated-delta wing vortex generators," Applied Thermal Engineering, vol. 100, pp. 611-620, 2016.

[9] A. Hachemi, "Experimental study of thermal performance of offset rectangular plate fin absorber-plates," Renewable Energy, vol. 17, pp. 371-384, 1999.

[10] S. Karsli, "Performance analysis of new-design solar air collectors for drying applications," Renewable Energy, vol. 32, pp. 1645-1660, 2007.

[11] N. Moummi, S. Youcef-Ali, A. Moummi, and J. Desmons, "Energy analysis of a solar air collector with rows of fins," Renewable Energy, vol. 29, pp. 2053-2064, 2004.

[12] C. D. Ho, H. Chang, R. C. Wang, and C. S. Lin, "Performance improvement of a double-pass solar air heater with fins and baffles under recycling operation," Applied Energy, vol. 100, pp. 155-163, 2012.

[13] İ. Kurtbas and A. Durmus, "Efficiency and exergy analysis of a new solar air heater," Renewable Energy, vol. 29, pp. 14891501, 2004.

[14] H. M. Yeh, C. D. Ho, and J. Z. Hou, "Collector efficiency of double-flow solar air heaters with fins attached," Energy, vol. 27, pp. 715-727, 2002.

[15] D. Peng, X. Zhang, H. Dong, and K. Lv, "Performance study of a novel solar air collector," Applied Thermal Engineering, vol. 30, pp. 2594-2601, 2010.

[16] N. S. Deo, S. Chander, and J. S. Saini, "Performance analysis of solar air heater duct roughened with multigap V-down ribs combined with staggered ribs," Renewable Energy, vol. 91, pp. 484-500, 2016.

[17] V. S. Hans, R. P. Saini, and J. S. Saini, "Heat transfer and friction factor correlations for a solar air heater duct roughened artificially with multiple v-ribs," Solar Energy, vol. 84, pp. 898-911, 2010.

[18] V. K. Chouksey and S. P. Sharma, "Investigations on thermal performance characteristics of wire screen packed bed solar air heater," Solar Energy, vol. 132, pp. 591-605, 2016.

[19] S. Bouadila, S. Kooli, M. Lazaar, S. Skouri, and A. Farhat, "Performance of a new solar air heater with packed-bed latent storage energy for nocturnal use," Applied Energy, vol. 110, pp. 267-275, 2013.

[20] C. Christensen, E. Hancock, G. Barker, and C. Kutscher, "Cost and performance predictions for advanced active solar concepts," in Proceedings of the Annual Conference, American Solar Energy Society, Inc, pp. 275-280, USA, 1990.

[21] C. F. Kutscher, C. B. Christensen, and G. M. Barker, "Unglazed transpired solar collectors: heat loss theory," Journal of Solar Energy Engineering, vol. 115, p. 182, 1993.

[22] L. H. Gunnewiek, E. Brundrett, and K. G. T. Hollands, "Flow distribution in unglazed transpired plate solar air heaters of large area," Solar Energy, vol. 58, pp. 227-237, 1996.

[23] L. H. Gunnewiek, K. G. T. Hollands, and E. Brundrett, "Effect of wind on flow distribution in unglazed transpired," Solar Energy, vol. 72, pp. 317-325, 2002.

[24] T. Børvik, O. S. Hopperstad, T. Berstad, and M. Langseth, "Perforation of $12 \mathrm{~mm}$ thick steel plates by $20 \mathrm{~mm}$ diameter projectiles with flat, hemispherical and conical noses part II: numerical simulations," International Journal of Impact Engineering, vol. 27, pp. 37-64, 2002.

[25] K. Gawlik, C. Christensen, and C. Kutscher, "A numerical and experimental investigation of low-conductivity unglazed, transpired solar air heaters," Journal of Solar Energy Engineering, vol. 127, p. 153, 2005.

[26] C. B. Christensen, C. F. Kutscher, and K. M. Gawlik, "Unglazed transpired solar collector having a low thermal conductance absorber," US Patent 5,692,491, 1997.

[27] R. Vaziri, M. Ilkan, and F. Egelioglu, "Experimental performance of perforated glazed solar air heaters and unglazed transpired solar air heater," Solar Energy, vol. 119, pp. 251-260, 2015.

[28] J. P. Holman, Experimental Methods for Engineers, McGrawHill, 453 New York, 1989.

[29] S. V. Karmare and A. N. Tikekar, "Experimental investigation of optimum thermohydraulic performance of solar air heaters with metal rib grits roughness," Solar Energy, vol. 83, pp. 6-13, 2009.

[30] R. Nowzari, L. B. Y. Aldabbagh, and F. Egelioglu, "Single and double pass solar air heaters with partially perforated cover and packed mesh," Energy, vol. 73, pp. 694-702, 2014.

[31] S. B. Prasad, J. S. Saini, and K. M. Singh, "Investigation of heat transfer and friction characteristics of packed bed solar air heater using wire mesh as packing material," Solar Energy, vol. 83, pp. 773-783, 2009. 

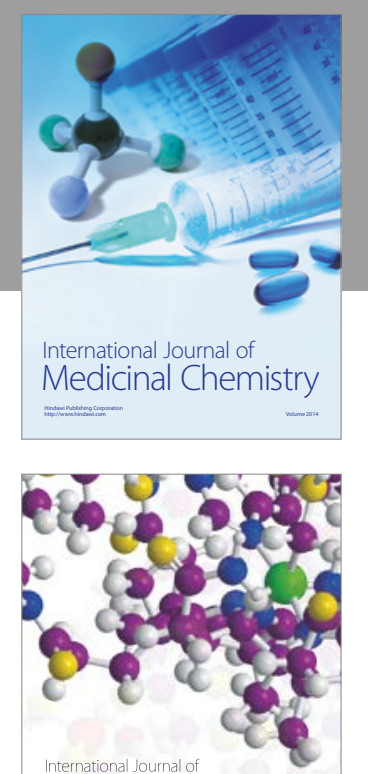

Carbohydrate Chemistry



The Scientific World Journal
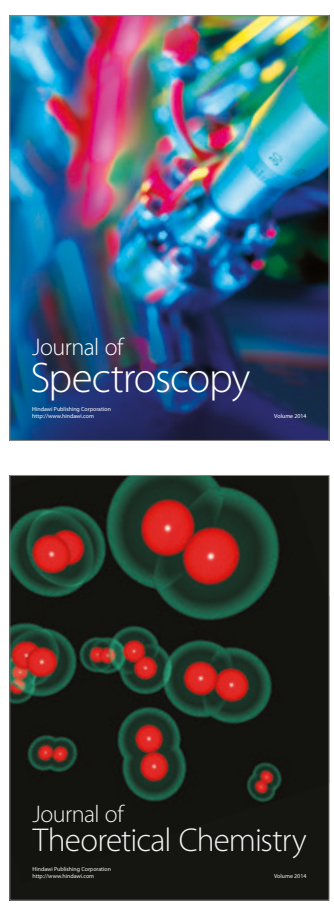
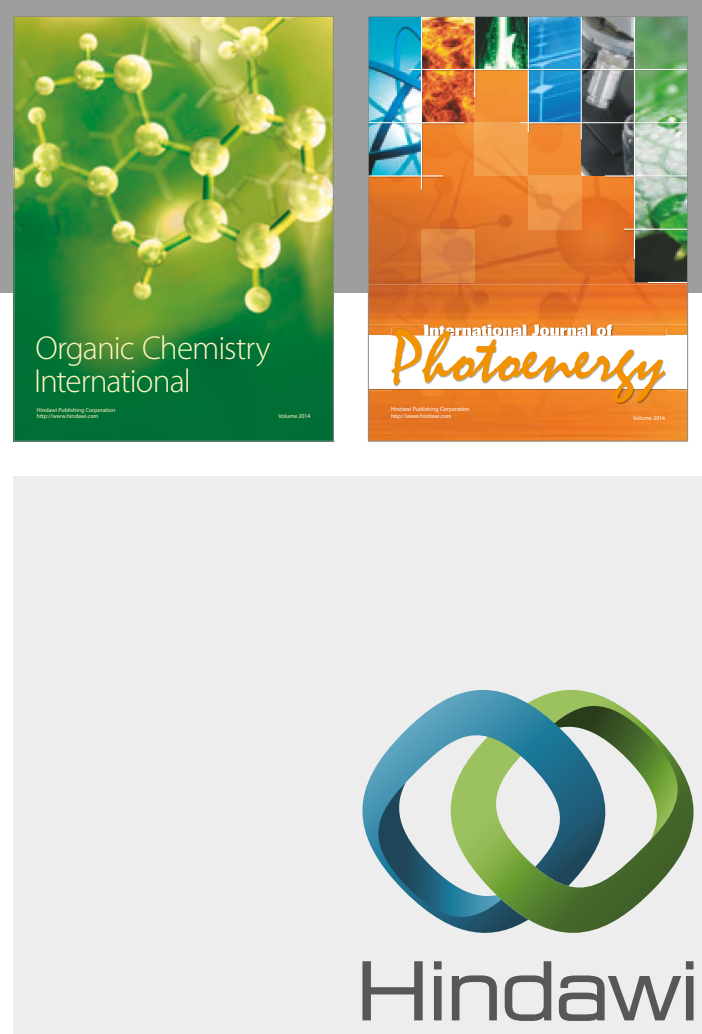

Submit your manuscripts at

https://www.hindawi.com

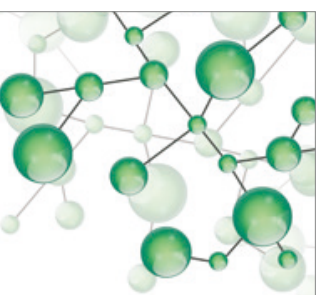

International Journal of

Inorganic Chemistry

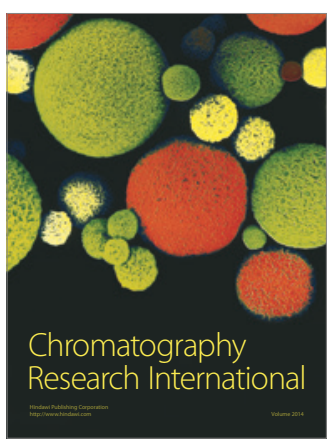

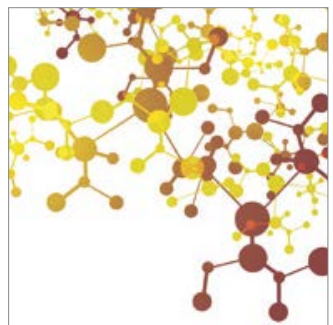

Applied Chemistry

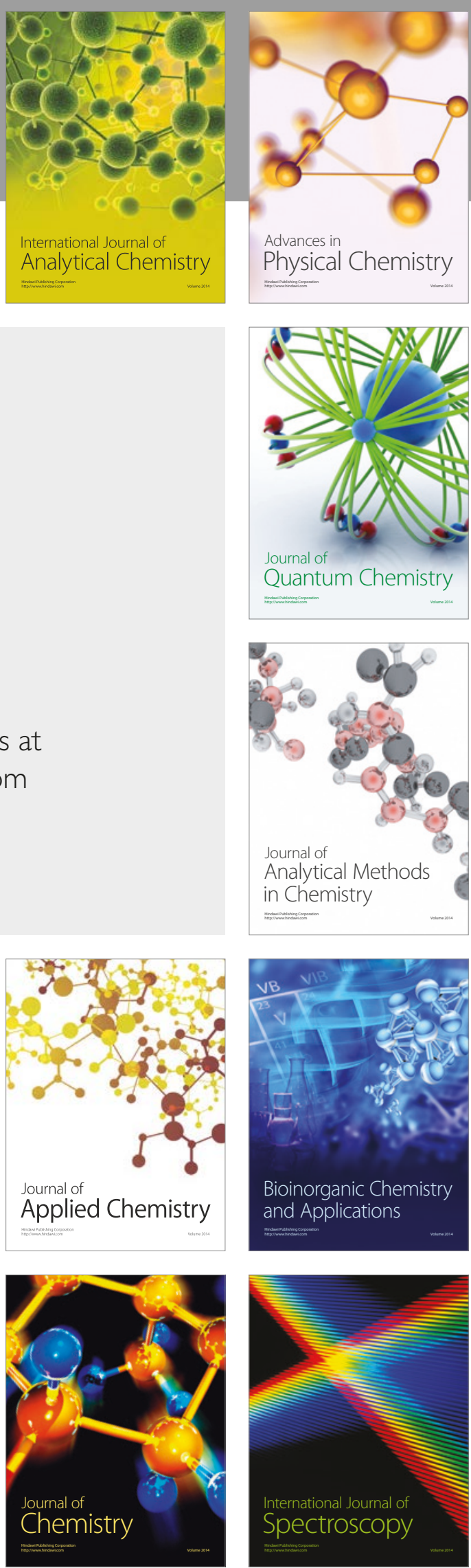